University of Nebraska - Lincoln

DigitalCommons@University of Nebraska - Lincoln

Selection for Biomass Yield in Upland, Lowland, and Hybrid Switchgrass

\author{
Michael D. Casler \\ USDA-ARS, michael.casler@ars.usda.gov \\ Kenneth P. Vogel \\ University of Nebraska-Lincoln, kvogel1@unl.edu
}

Follow this and additional works at: https://digitalcommons.unl.edu/usdaarsfacpub

Casler, Michael D. and Vogel, Kenneth P., "Selection for Biomass Yield in Upland, Lowland, and Hybrid Switchgrass" (2014). Publications from USDA-ARS / UNL Faculty. 1977.

https://digitalcommons.unl.edu/usdaarsfacpub/1977

This Article is brought to you for free and open access by the U.S. Department of Agriculture: Agricultural Research Service, Lincoln, Nebraska at DigitalCommons@University of Nebraska - Lincoln. It has been accepted for inclusion in Publications from USDA-ARS / UNL Faculty by an authorized administrator of DigitalCommons@University of Nebraska - Lincoln. 


\title{
Selection for Biomass Yield in Upland, Lowland, and Hybrid Switchgrass
}

\author{
Michael D. Casler^ and Kenneth P. Vogel
}

\begin{abstract}
Switchgrass (Panicum virgatum L.) is a candidate for cellulosic bioenergy feedstock development in many parts of North America, Europe, and Asia. Breeding for increased biomass yield is a viable and desirable research objective to improve both economic and energy yields per hectare. The objectives of this study were to estimate progress from (i) selection for biomass yield in upland switchgrass, (ii) selection for winter survival, biomass yield, and biomass quality in lowland switchgrass, and (iii) advanced-generation heterosis effects in four upland $\times$ lowland hybrid switchgrass populations. Selection for increased biomass yield in upland switchgrass resulted in mean genetic gains for of 0.71 $\mathrm{Mg} \mathrm{ha}^{-1}$ per cycle $\left(8 \%\right.$ per cycle $\left.=4 \% \mathrm{yr}^{-1}\right)$ for biomass yield. Selection for increased biomass yield in lowland switchgrass resulted in mean genetic gains of $0.89 \mathrm{Mg} \mathrm{ha}^{-1}\left(18 \%=1 \% \mathrm{yr}^{-1}\right)$ for biomass yield. Mean high-parent heterosis between upland and lowland ecotypes was $3.57 \mathrm{Mg} \mathrm{ha}^{-1}$ (43\%). These gains in biomass yield resulted in significant increases in ethanol production for a fermentation platform or high heating value for a combustion platform. Biomass yield is a moderately heritable trait in switchgrass and it can be readily improved in both upland and lowland populations using conventional breeding methods.
\end{abstract}

M. Casler, USDA-ARS, U.S. Dairy Forage Research Center, 1925 Linden Dr., Madison, WI 53706-1108; K.P. Vogel, USDA-ARS, Univ. Nebraska, Lincoln, NE 68583-0937. Received 9 Apr. 2013. *Corresponding author (michael.casler@ars.usda.gov).

Abbreviations: ADF, acid detergent fiber; ADL, acid detergent lignin; ARDC, Agricultural Research and Development Center; BFDP, Bioenergy Feedstock Development Program; DOY, day of the year; E, early maturity; (f), female parent; HYLD, high biomass yield; HZ, USDA hardiness zone; K, Kanlow; L, late maturity; NDF, neutral detergent fiber; NETO, Nebraska Ethanol Index; NIRS, near-infrared reflectance spectroscopy; S, Summer; Syn, synthetic.

Wwitchgrass is a candidate for cellulosic bioenergy feedstock development in many parts of North America, Europe, and Asia. Research focused on development of switchgrass as a bioenergy feedstock was initiated in 1992 as part of the U.S. Department of Energy Bioenergy Feedstock Development Program (BFDP) (Sanderson et al., 2007). Before this program, research on switchgrass beginning in the mid 1930s had been focused on its use in grazing systems in the Great Plains and the Midwestern United States. Two early objectives of the BFDP included (i) agronomic studies to identify superior cultivars and their optimal production ranges and (ii) initiation of germplasm collection and breeding efforts to improve switchgrass. Studies focused on the former objective identified two cultivars, Alamo and Cave-in-Rock, with superior adaptation ranges, spanning numerous USDA hardiness zones (HZs) (Casler et al., 2004, 2007a; Fike et al., 2006; Sanderson et al., 1999). Conversely, most cultivars have narrower adaptation ranges, such that optimal biomass production can be achieved only within one hardiness zone of their origin (Casler et al., 2007a;

\footnotetext{
Published in Crop Sci. 54:626-636 (2014).

doi: $10.2135 /$ cropsci2013.04.0239

C Crop Science Society of America | 5585 Guilford Rd., Madison, WI 53711 USA

All rights reserved. No part of this periodical may be reproduced or transmitted in any form or by any means, electronic or mechanical, including photocopying, recording, or any information storage and retrieval system, without permission in writing from the publisher. Permission for printing and for reprinting the material contained herein has been obtained by the publisher.
} 
Vogel et al., 2005). Identification and characterization of these adaption restrictions and associated improvements in biomass yield is partly responsible for the $25 \%$ decrease in estimated production costs for switchgrass for the 10-yr duration of the BFDP. This paper reports on genetic gains from up to $15 \mathrm{yr}$ of breeding switchgrass for increased biomass yield in Nebraska and Wisconsin.

Multidisciplinary communication and interaction were key elements of the BFDP, which provided a venue for plant breeders, molecular biologists, agronomists, modelers, and economists to interact with each other. Early BFDP studies, focused on economics, life-cycle analysis, and sustainability, identified biomass production and conversion costs as factors limiting rapid deployment and adoption of switchgrass as a bioenergy feedstock (McLaughlin and Kszos, 2005). Plant breeders quickly focused on breeding for increased biomass yield as a low-risk investment toward increasing biomass yield potential and reducing production costs. Using knowledge of adaptation zones and germplasm diversity (Casler et al., 2012), regional breeding programs were established in Georgia, Oklahoma, Nebraska, and Wisconsin, each focused on a different region of the United States (Sanderson et al., 2007). As the number of breeding programs expanded in the 21st century, regional gene pools were proposed to function as geographic target regions for germplasm collection, selection, and cultivar deployment, based on a combination of hardiness zones and ecoregions (Casler et al., 2012).

Breeding work to improve switchgrass as a forage crop between 1950 and 1990 involved germplasm collections and evaluations followed by either direct release of superior accessions as cultivars or by breeding for specific traits such as forage digestiblity, seed yield, and seed quality (Vogel, 2004). Cultivar evaluations verified that there were still significant untapped genetic resources for superior biomass and bioenergy traits in remnant prairie populations (Casler et al., 2004, 2007a; Hopkins et al., 1993, 1995; Sanderson et al., 1999). The Georgia and Oklahoma breeding programs, using germplasm source populations with no previous breeding history, demonstrated the feasibility of increasing biomass yield by selection of plants with superior vigor and biomass yield potential in spaced-planted nurseries. Genetic gains in biomass yield of sward plots were realized following one cycle of selection using spatial adjustments of biomass yield for unreplicated spaced plants to adjust for environmental variation (Missaoui et al., 2005). A direct comparison of selection in high- vs. low-yield environments indicated that realized gains were greatest in the low-yield environments (Rose et al., 2007). In the ARS breeding program at the University of Nebraska, recurrent phenotypic selection improved biomass digestibility of upland switchgrass populations but did not improve biomass yield of populations that had been developed by several previous generations of breeding for yield and other traits (Hopkins et al., 1993). Recently this project demonstrated that use of among-and-within-family breeding strategies resulted in improved biomass yield of upland switchgrass populations with previous breeding history for biomass yield (Vogel, 2013). In addition to these intrapopulation improvement approaches, heterosis between contrasting upland and lowland ecotypes has been documented in switchgrass, creating additional improvement possibilities (MartinezReyna and Vogel, 2008; Vogel and Mitchell, 2008).

The objectives of this study were to measure and test the following biomass-yield improvement efforts in switchgrass: (i) three cycles of selection for biomass yield in WS4U upland switchgrass, (ii) one cycle of selection for winter survival followed by selection for seedling vigor, biomass yield, and quality traits in Kanlow-derived lowland switchgrass populations, and (iii) selection for seedling vigor, biomass yield, and quality traits in four upland $\times$ lowland advancedgeneration hybrid switchgrass populations.

\section{MATERIALS AND METHODS Germplasm Development WS4U Upland Switchgrass Populations}

Three cycles of selection were conducted in the WS4U switchgrass population, a broad-based germplasm pool made up of 150 tetraploid upland-cytotype parents of diverse origins (Casler et al., 2006). Selections derived from WS4U are expected to be adapted to hardiness zones 3 to 5 east of the Great Plains region of North America. Seeds of each family were germinated in a glasshouse in January 2001 and transplanted to the field in May 2001. The experimental design of the spaced-plant nursery was a randomized complete block with four replicates. Each plot consisted of 10 plants from one family, transplanted on a $0.3-\mathrm{m}$ spacing within plots and $0.9-\mathrm{m}$ spacing between plots. Weeds were controlled by application of $1.12 \mathrm{~kg} \mathrm{ha}^{-1}$ alachlor [2-chloro$\mathrm{N}-2,6$-diethylphenyl)-N-(methoxymethyl)-acetamide] with $0.07 \mathrm{~kg} \mathrm{ha}^{-1}$ imazethapyr $\{( \pm)-2-[4,5$-dihydro-4-methyl-4-(1methylethyl)-5-oxo-1H-imidazol-2-yl]-5-ethyl-3-pyridinecarboxylic acid\}. All biomass was removed in September 2001 before the onset of winter.

The nursery was fertilized with $110 \mathrm{~kg} \mathrm{~N} \mathrm{ha}^{-1}$ before the initiation of growth in spring 2002. Preemergence herbicides were also applied before initiation of growth, exactly as described for the 2001 application. Before anthesis eight plants were culled from the 10 present in each plot using a sickle-bar mower. Selection was based almost exclusively on visual estimation of biomass yield. The remaining $20 \%$ of the nursery was allowed to pollinate in isolation from other sources of switchgrass. Seed was harvested in late September on one plant of each row, with selection based on visual biomass, seed production, and disease reaction. Seeds were bulked in equal quantities across the four replicates within a family, creating 150 new seed bulks (families). Cycles 2 and 3 were completed in 2003 through 2004 and 2005 through 2006, respectively, following the same protocols. Selection led to the creation of three new populations: WS4U-C1, WS4U-C2, and WS4U-C3. 
Three cycles of random seed increase within WS4U were generated as a control for evaluation of the effects of selection vs. drift. Four random plants from each family were established in a completely randomized design at Arlington in 2001, creating a 600-plant nursery, with the number of plants chosen to be identical to the number of parents contributing gametes to the next generation in the biomass-yield selection scheme described above. Plants were spaced $0.9 \mathrm{~m}$ apart in perpendicular directions; fertilization and weeding were conducted exactly as described above. Five panicles were harvested from each plant in 2002 to create the WS4U synthetic (Syn) 2 population, the first generation of random seed increase from the original halfsib families that represented Syn 1. This process was repeated for a second generation in 2003 through 2004 and a third generation in 2005 through 2006 (Syn 3 and Syn 4).

Finally, two single cycles of natural selection for survivorship were conducted in these 150 maternal families. Sward plots were drilled in replicated experiments at two locations in each cycle. Locations were Arlington and Marshfield, WI; management and data collection on sward plots were described previously (Casler, 2010). Following 2 yr of biomass harvest on the sward plots, seed was harvested on the 41-mo-old plots, at the end of the fourth growing season. Ten random panicles were harvested from 10 different positions within each plot. Seed was threshed and cleaned for each plot and bulked in equal quantities across 450 replicated family plots at each location. The first cycle of natural selection was conducted within sward plots of the original WS4U half-sib families, creating the populations (WS4U-N1a from Arlington and WS4U-N1m from Marshfield). The second cycle of natural selection was conducted within sward plots of the WS4U-C1 half-sib families, creating the populations (WS4U-N2a from Arlington and WS4U-N2m from Marshfield). In total, 10 WS4U-derived populations were created from these selection protocols.

a) WS4U-C1, WS4U-C2, and WS4U-C3, selected for biomass yield.

b) WS4U Syn 2, WS4U Syn 3, and WS4U Syn 4, three generations of random seed increase from WS4U Syn 1.

c) WS4U-N1a, WS4U-N1m, WS4U-N2a, and WS4U$\mathrm{N} 2 \mathrm{~m}$, created by seed harvest on natural selection survivors.

Efforts to improve upland switchgrass at Lincoln, NE, were focused on selection within the cultivar Cave-in-Rock. The first cycle of selection for increased biomass yield and biomass quality led to the release of the cultivar Shawnee, as described by Vogel et al. (1996). Two subsequent cycles, using similar selection criterion and population sizes resulted in CIRHYD-HDMD-C3, which was included in this experiment.

\section{Kanlow-Derived Lowland Switchgrass Populations}

Kanlow is a tetraploid lowland cultivar based on a germplasm collection made near Wetumka, OK (Alderson and Sharp, 1994). Kanlow has high biomass yields but has winter survival problems north of $40^{\circ} \mathrm{N}$ latitude in North America. The base Kanlow Nebraska 1 (K N1) population was developed by one generation of selection for winter survival at the University of Nebraska's Agricultural Research and Development Center
(ARDC) $\left(41.17^{\circ} \mathrm{N}, 96.47^{\circ} \mathrm{W}\right)$. A population of 400 Kanlow plants, grown from Kanlow Foundation seed, was established at the ARDC in 1995. Another population of 150 plants produced from Kanlow $\times$ Kanlow single-plant matings was established at the ARDC in 1997. These selection nurseries were managed similar to those at Madison except the plants were on 1.1-m centers and were rototilled bidirectionally each spring to maintain the plants as $0.2-\mathrm{m}^{2}$ minisward plots. The nurseries were burned each spring to remove the previous year's biomass production, facilitating spring regrowth evaluations. In the spring of 1999, after significant winter injury had occurred in these nurseries the previous winters, 72 plants with no winter injury, good spring vigor, and minimal lodging were selected for polycrossing from these two nurseries. Two ramets of each selected genotype were moved to an isolated polycross nursery, which was used to produce K N1 Syn 1 seed in 1999 and 2000. The Syn 1 seed was used to establish a seed increase nursery that produced K N1 Syn 2 seed.

Approximately 3000 K N1 Syn1 seedlings were established in $3.8-$ by $14-\mathrm{cm}$ cone-shaped pots. After seedlings had emerged, they were thinned to one per cell. Six weeks after emergence, the 20 most vigorous seedlings within each of 30 trays of 98 seedlings were selected for transplanting into a field selection nursery at the University of Nebraska's ARDC in the spring of 2002. The selection nursery was a space-planted nursery with 30 rows of 20 plants on 1.1-m centers and was managed the same as those described previously. No winter injury occurred during the first two winters. In mid August 2004, when the plants were at the R2 (or panicle emergence stage of maturity) (Moore et al., 1991), seven plants (35\%) per row were visually selected for biomass sampling and harvest for yield. Before the yield harvest with a flail-type harvester, approximately five tillers were sampled from each selected plant. The individual plants were then harvested for yield. Cutting height was $10 \mathrm{~cm}$ for both tiller samples and plant harvest.

The sampled tillers were oven dried to determine dry matter concentration. Dry matter concentration and dried tiller mass were used to determine total dry matter yields per plant. The dried tillers were hand separated into leaf, sheath, stem, and panicle components. The tillers were ground and scanned for their near-infrared reflectance spectroscopy (NIRS) spectra profiles using a Model 6500 near-infrared spectrometer (NIRSystems; now FOSS NIRSystems, Inc. $\left.{ }^{1}\right)$. A subset of the samples plus a subset of stem samples from the lowland $\times$ upland hybrid populations (see following material) selected to represent the spectral diversity of the samples were analyzed for neutral detergent fiber (NDF), acid detergent fiber (ADF), acid detergent lignin (ADL), and ash using the ANKOM Fiber Analyzer ${ }^{1}$ (ANKOM Technology Corp.) and the procedures described by Vogel et al. (1999). The laboratory data was used to develop NIRS calibrations for switchgrass stem NDF, ADF, ADL, and ash using the procedures described by Vogel et al. (2011). The NDF, ADF, and ADL composition of all stem samples was then predicted using the NIRS calibrations. This data was used to calculate stem cellulose concentration (ADF minus ADL) and stem lignin concentration

${ }^{1}$ USDA neither guarantees nor warrants the standard of the product, and the use of the name by USDA implies no approval of the product to the exclusion of others that may also be suitable. 
Table 1. Location information for four evaluations sites of selected switchgrass populations.

\begin{tabular}{lcccc}
\hline \multicolumn{1}{c}{ Location } & Latitude & Longitude & $\mathrm{HZ}^{\dagger}$ & Soil type and taxonomy \\
\hline & ${ }^{\circ} \mathrm{N}$ & ${ }^{\circ} \mathrm{W}$ & & \\
DeKalb, IL & 41.88 & 88.73 & $5 \mathrm{~b}$ & Drummer silty clay loam (fine-silty, mixed, mesic Typic Endoaquoll) \\
Arlington, WI & 43.33 & 89.38 & $4 \mathrm{~b}$ & Plano silt loam (fine-silty, mixed, mesic Typic Argiudoll) \\
Marshfield, WI & 44.65 & 90.13 & $4 \mathrm{a}$ & Withee silt loam (fine-loamy, mixed, superactive frigid Aquic Glossudalf) \\
Spooner, WI & 45.80 & 72.87 & $3 \mathrm{~b}$ & Murrill silt loam (fine-loamy, mixed, mesic Typic Hapludult) \\
\hline
\end{tabular}

${ }^{+} H Z$ = USDA hardiness zone (Cathey, 1990; USDA-ARS, 2012).

(ADL minus ash). In 2005, heading date was scored on all plants in the nursery as the day of the year (DOY) that the majority of the tillers of a plant were at the R2 stage of maturity.

Based on the biomass yield, stem cellulose and ADL concentration, and maturity, the following K N1 derived populations were developed:

a) KN1 L HYLD: 30 plants selected for late maturity (L) (DOY > 228 and high biomass yield (HYLD).

b) KN1 E HYLD: 15 plants selected for early maturity (E) $(\mathrm{DOY}<224)$ and high biomass yield.

c) KN1 NETO2: 25 plants selected for high biomass yield and low stem lignin using a selection index that weighted each trait equally (Nebraska Ethanol Index 2 or NETO2).

d) KN1 NETO3: 28 plants selected for high biomass yield and high stem cellulose concentration using a selection index that weighted each equally (Nebraska Ethanol Index 3 or NETO3).

Two ramets of each selected plant were transplanted into their respective isolated polycross nursery. Some selected genotypes were included in more than one derived population. Seed was harvested in bulk from the polycross nurseries for use in yield tests.

\section{Summer (S) $\times$ Kanlow (K), Upland $\times$ Lowland Hybrid Populations}

Summer is a tetraploid, upland cultivar that is based on germplasm collected in southeast Nebraska (Alderson and Sharp, 1994). Summer (S) $\times \mathrm{K} \mathrm{F}_{1}$ hybrids were developed by paired crossing in the greenhouse, as described by Martinez-Reyna and Vogel (2008). $\mathrm{K} \times \mathrm{S}(\mathrm{f})$ and $\mathrm{S} \times \mathrm{K}(\mathrm{f})$ plants not required to support the experiments of Martinez-Reyna and Vogel (2008) were transplanted into a field holding and evaluation nursery where they were maintained as separate populations using the same procedures described previously for selection nurseries. In the autumn of 1998, vigorous, 2-yr-old, nonlodged plants were selected for polycrossing from the holding nurseries. Fifty plants each were selected from the $\mathrm{K} \times \mathrm{S}(\mathrm{f})$ population and $\mathrm{S} \times \mathrm{K}(\mathrm{f})$ populations. Ramets or clonal pieces of the selected plants from the two populations of $F_{1}$ plants were transplanted in separate isolated polycross nurseries, which were use to produce Syn 2 seed by bulk harvesting seed from the selected $F_{1}$ plants. The Syn 2 from each population was used to produce 600 seedlings, which were transplanted into different polycross isolations for Syn 3 seed.

Seed of the Syn 3 generation was used to begin population improvement in each of the two derived populations, $\mathrm{K} \times \mathrm{S}(\mathrm{f})$ and $\mathrm{S} \times \mathrm{K}(\mathrm{f})$, which differ in cytoplasm background. Greenhouse selection for seedling vigor was conducted using the same procedures as described above for the K N1 population. The selected seedlings of each population were transplanted to field selection nurseries using the same procedures as described above for K N1 and the same evaluation nurseries and selection procedures were followed as described for the K N1 populations. Based on biomass yield and stem lignin concentration, the following populations were developed.

d) $\mathrm{K} \times \mathrm{S}(\mathrm{f}) \mathrm{HYLD} \mathrm{C} 1 \mathrm{:} 34$ plants selected for high biomass yield.

e) $\mathrm{K} \times \mathrm{S}(\mathrm{f}) \mathrm{NETO} 2: 34$ plants selected for high biomass yield and low stem lignin using a selection index that weighted each trait equally (NETO2).

f) $\mathrm{S} \times \mathrm{K}(\mathrm{f}) \mathrm{HYLD}$ : 34 plants selected for high biomass yield.

g) $\mathrm{S} \times \mathrm{K}(\mathrm{f}) \mathrm{NETO}$ : 35 plants selected for high biomass yield and low stem lignin using a selection index that weighted each trait equally (NETO2).

Two ramets of each selected plant were transplanted into their respective isolated polycross nursery. Some selected genotypes were included in more than one derived population. Seed was harvested in bulk from the polycross nurseries for use in yield tests.

\section{Field Evaluations of Selected Populations}

The populations described above plus 14 additional upland check cultivars were planted in replicated field experiments in May or June 2008. Plots were planted at four locations in Wisconsin and Illinois (Table 1). Plots were 0.9 by $1.8 \mathrm{~m}$ and consisted of five drilled rows. Each experiment was a randomized complete block with four replicates. Biomass was removed after killing frost of the establishment year, but there was no fertilizer or herbicide applied during that year.

Plots were fertilized with $110 \mathrm{~kg} \mathrm{~N} \mathrm{ha}^{-1}$ in spring of 2009 through 2011. Biomass yield was determined by harvesting each plot with a flail-type harvester at the time of killing frost in 2009 through 2011. Random samples of approximately 300 to $500 \mathrm{~g}$ were collected for dry matter determination from each plot immediately before harvest. Ground cover was determined immediately after harvest in 2011 using a 50-cell grid as described by Vogel and Masters (2001). Samples were dried at $60^{\circ} \mathrm{C}$ in a forced-air dryer, ground once through a $1-\mathrm{mm}$ screen of a Wiley-type mill, and scanned using NIRS. Cluster analysis of reflectance spectra (Shenk and Westerhaus, 1991) was used to develop a subset of 110 samples for calibration development (Vogel et al., 2011). These robust NIRS equations were used to 
predict ethanol production potential and high heating value for each sample, based on wet-laboratory procedures described by Vogel et al. (2011) and Núñez-Regueira et al. (2001). The two quality traits were each expressed as a concentration or proportion of total dry matter and as a yield or production value per hectare (concentration multiplied by biomass yield).

Data were analyzed by linear mixed models analysis, combined over years and locations, treating locations, years, and populations as fixed effects and replicates as a random effect (Littell et al., 1996). Contrasts were used to test the effects of selection and drift effects within the WS4U selection populations. Contrasts were used to test the effects of selection within the Kanlow-derived selections, specifically Kanlow vs. selections and selection for biomass yield vs. index selection for high yield and quality. For the hybrid populations, contrasts were used to test reciprocal effects, both midparent and high-parent heterosis effects, and the effects of selection for biomass yield vs. index selection for high yield and quality. Contrasts were also used to make comparisons across ecotypes and groups of populations.

\section{RESULTS}

\section{Selection within Upland Switchgrass}

Responses of biomass yield to three cycles of spaced-plant selection were heterogeneous across the four evaluation locations (Fig. 1). The greatest responses were observed at Arlington and Marshfield, WI (0.89 to $0.96 \mathrm{Mg} \mathrm{ha}^{-1}$ per cycle $=10$ to $13 \%$ per cycle $=5$ to $\left.7 \% \mathrm{yr}^{-1}\right)$. Biomass yield responses were also significant at Spooner, WI (0.49 $\mathrm{Mg} \mathrm{ha}^{-1}$ per cycle $=6 \%$ per cycle $=3 \% \mathrm{yr}^{-1}$ ) but only of marginal statistical significance at DeKalb, IL $(0.50 \mathrm{Mg}$ $\mathrm{ha}^{-1}$ per cycle $=5 \%$ per cycle $=2.5 \% \mathrm{yr}^{-1}$ ).

The parallel cyclic seed increase of random plants within the WS4U population was not significant at any location (Fig. 1). As expected, the trajectory of biomass yield across three generations of seed increase without selection was completely random, without any indication of selection effects. Only averaged across all four locations was there any evidence of a response, which was negative $\left(-0.34 \mathrm{Mg} \mathrm{ha}^{-1}\right.$ per cycle $=-4 \%$ per cycle; $\left.P=0.0253\right)$. Similarly, seed harvest on 3-yr survivors of natural selection within swards did not result in any realized gains at the individual evaluation locations but a significant average response for Cycle 2 averaged across locations $(-1.01$ $\mathrm{Mg} \mathrm{ha}^{-1}$ per cycle $=-11 \%$ per cycle; $\left.P=0.0255\right)$.

Three cycles of selection within WS4U were sufficient to make this population competitive with other highyielding upland cultivars at all four locations (Table 2). In addition, three cycles of selection for increased biomass yield within Cave-in-Rock led to a significant improvement of $12.9 \%$ in biomass yield of CIR-HYD-HDMDC3. This latter increase was equivalent to gains of approximately $0.7 \% \mathrm{yr}^{-1}$ for biomass yield. More importantly, selection gains made in USDA HZ5 (Lincoln, NE) were realized across three hardiness zones (HZ3 through HZ5) in this experiment.

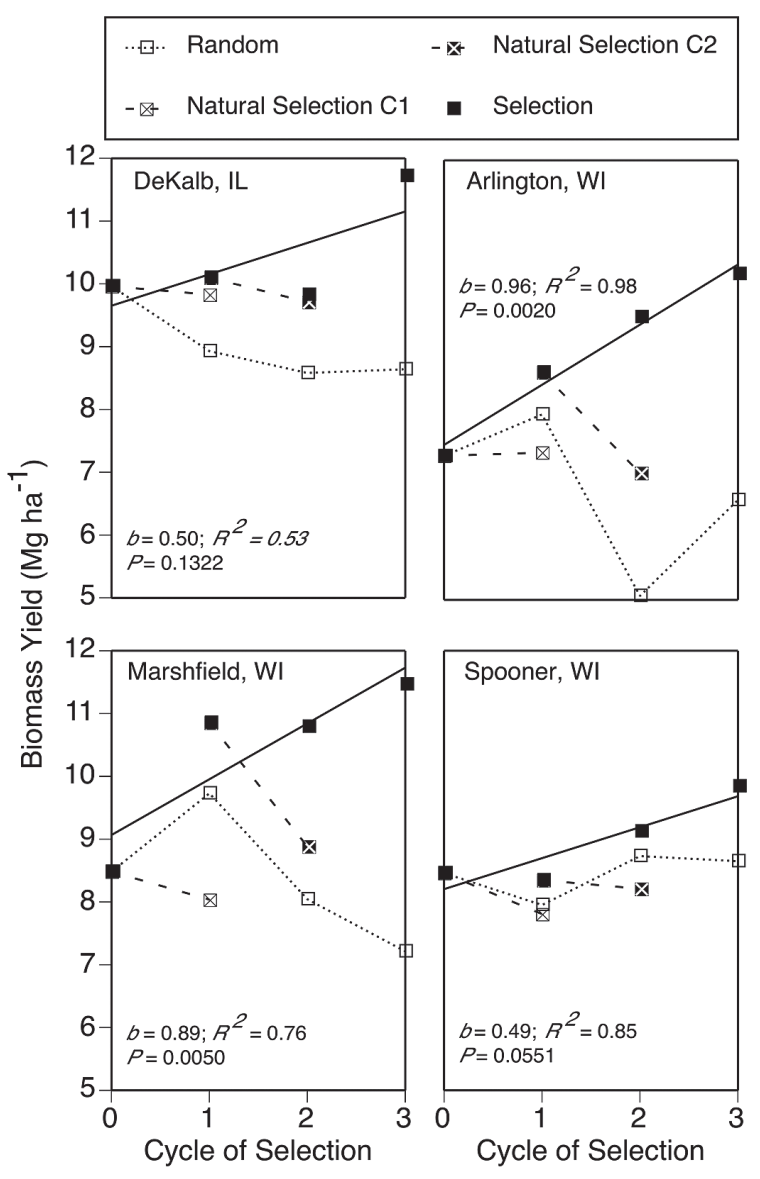

Figure 1. Trajectories of selection effects in the WS4U upland switchgrass population, including the effects of three cycles of visual selection for biomass yield of spaced plants, random seed increase for three generations, and two independent assessments of the effects of natural selection, one each in cycles 1 (C1) and 2 (C2).

Table 2. Mean biomass yield of the six upland switchgrass populations with the highest mean biomass yield across four evaluation locations. Means were computed over four replicates and 3 yr.

\begin{tabular}{lccccc}
\hline & \multicolumn{5}{c}{ Evaluation site } \\
\cline { 2 - 4 } Population & $\begin{array}{c}\text { DeKalb, } \\
\text { IL }\end{array}$ & $\begin{array}{c}\text { Arlington, } \\
\text { WI }\end{array}$ & $\begin{array}{c}\text { Marshfield, Spooner, } \\
\text { WI }\end{array}$ & WI & Mean \\
\cline { 2 - 5 } WS4U-C3 & 11.72 & 10.19 & 11.46 & 9.84 & 10.81 \\
Carthage & 11.93 & 13.57 & 8.60 & 8.30 & 10.60 \\
Cave-in-Rock & 10.45 & 13.42 & 8.43 & 9.97 & 10.57 \\
Shawnee & 12.93 & 12.80 & 11.08 & 9.47 & 11.57 \\
WS8U & 11.69 & 12.65 & 12.29 & 10.61 & 11.81 \\
CIR-HYD- & 11.79 & 13.00 & 12.60 & 10.32 & 11.93 \\
$\quad$ HDMD-C3 & & & & & \\
LSD(0.01) & 2.33 & 2.22 & 2.26 & 1.84 & 1.11 \\
\hline
\end{tabular}

Expressed on a unit dry matter basis, ethanol production potential and high heating value did not respond to any of the selection treatments within the WS4U population. Conversely, each variable, expressed on a perhectare basis, responded to selection when evaluated at both Arlington and Marshfield, the two locations with 

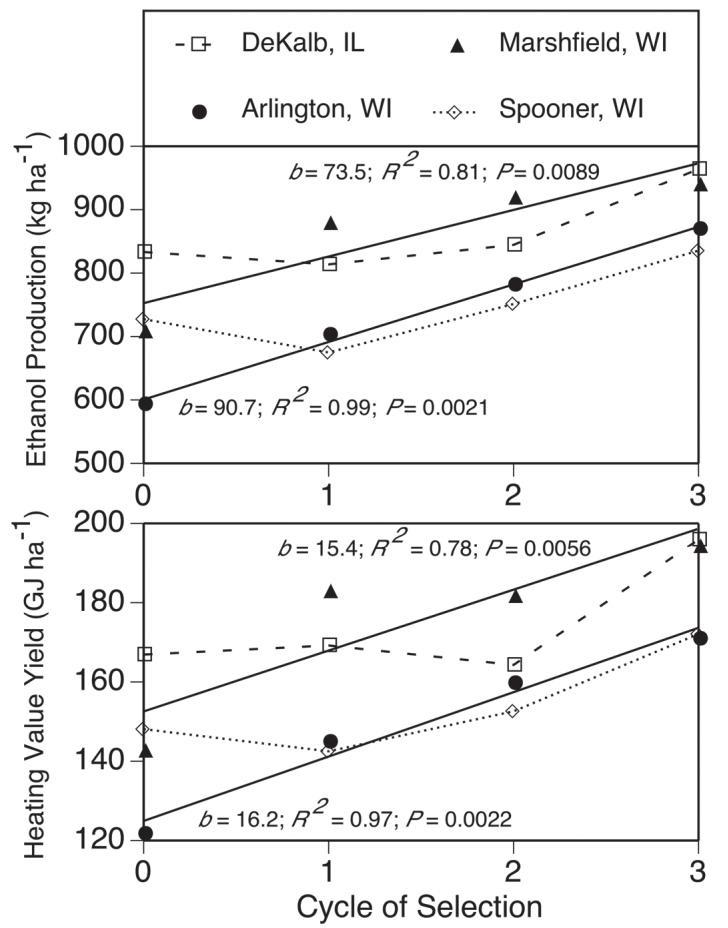

Figure 2. Correlated responses of ethanol production and high heating value production to three cycles of visual selection for biomass yield of spaced plants. Regression equations are shown for Arlington and Marshfield means, the only locations with significant responses across cycles.

the greatest observed response in biomass yield (Fig. 2). Ethanol production and heating value yield both increased linearly across selection cycles at these two locations. Observed responses for these two variables were not significant at DeKalb or Spooner, suggesting that there is a threshold effect related to biomass-yield realized gains, below which there is no impact on these quality traits. Biomass yield gains were likely not sufficiently large at DeKalb and Spooner to result in significant correlated responses for quality traits expressed on a per-hectare basis. This was probably a manifestation of genotype $\times$ environment interaction, as these two locations represented the greatest environmental deviation from the selection environment (Arlington).

\section{Selection within Lowland Switchgrass}

Responses of biomass yield and ground cover to selection within Kanlow lowland switchgrass were highly heterogeneous across evaluation locations (Table 3). Lowland switchgrass is not adapted to Spooner, being in HZ3b, clearly reflected in the low ground cover and biomass yield values observed during the three harvest years. This was further manifested in a lack of selection responses at this location. Lowland switchgrass is marginally adapted to Arlington and Marshfield, as evidenced by the higher values for both ground cover and biomass yield, compared to Spooner.
Table 3. Mean biomass yield and ground cover of Kanlow lowland switchgrass and five populations derived by selection from within Kanlow. Means were computed over four replicates and 3 yr.

\begin{tabular}{|c|c|c|c|c|c|}
\hline \multirow[b]{2}{*}{ Population $^{\dagger}$} & \multicolumn{4}{|c|}{ Evaluation site } & \multirow[b]{2}{*}{ Mean } \\
\hline & $\begin{array}{l}\text { DeKalb, } \\
\text { IL }\end{array}$ & $\begin{array}{c}\text { Arlington, } \\
\text { WI }\end{array}$ & $\begin{array}{c}\text { Marshfield, } \\
\text { WI }\end{array}$ & $\begin{array}{l}\text { Spooner, } \\
\text { WI }\end{array}$ & \\
\hline & \multicolumn{5}{|c|}{ Ground cover (\%) } \\
\hline Kanlow & 82 & 30 & 56 & 10 & 45 \\
\hline K N1 Syn 2 & 88 & 46 & 63 & 3 & 56 \\
\hline K N1 E HYLD & 86 & 43 & 76 & 3 & 67 \\
\hline KN1 L HYLD & 89 & 68 & 67 & 12 & 59 \\
\hline K N1 NETO2 & 91 & 66 & 78 & 18 & 64 \\
\hline K N1 NETO3 & 88 & 47 & 74 & 7 & 69 \\
\hline \multirow[t]{2}{*}{$\operatorname{LSD}(0.01)$} & 5 & 15 & 11 & 10 & 5 \\
\hline & \multicolumn{5}{|c|}{ Biomass yield $\left(\mathrm{Mg} \mathrm{ha}^{-1}\right)$} \\
\hline Kanlow & 9.20 & 4.57 & 3.16 & 2.52 & 4.87 \\
\hline KN1 Syn 2 & 10.54 & 4.99 & 3.64 & 2.80 & 5.50 \\
\hline K N1 E HYLD & 10.59 & 6.15 & 3.04 & 1.46 & 5.32 \\
\hline K N1 L HYLD & 12.58 & 5.60 & 5.52 & 2.47 & 6.55 \\
\hline K N1 NETO2 & 12.95 & 5.64 & 4.19 & 2.85 & 6.41 \\
\hline K N1 NETO3 & 12.42 & 4.24 & 3.77 & 3.13 & 5.90 \\
\hline $\operatorname{LSD}(0.01)$ & 2.33 & 2.22 & 2.26 & 1.84 & 1.11 \\
\hline
\end{tabular}

tE, early maturity; HYLD, high biomass yield; K, Kanlow; L, late maturity; NETO, Nebraska Ethanol Index; Syn, synthetic.

A single cycle of selection for survivorship in Kanlow (K N1 Syn 2 vs. Kanlow) increased ground cover at DeKalb and Arlington $(P<0.01)$, and this effect was of sufficient size to also be significant when averaged across the four locations (Table 3). A second cycle of selection for high biomass yield (K N1 E HYLD, K N1 L HYLD, K N1 NETO2, and K N1 NETO3 vs. K N1 Syn 2) resulted in some significant increases in ground cover measured at two of the four locations: 46 to $67 \%$ in two populations measured at Arlington and 63 to $76 \%$ in three populations measured at Marshfield $(P<0.01)$.

For biomass yield, the greatest responses were observed at DeKalb, located in HZ5a, which is the location most similar to the selection location, Lincoln, NE. Three individual populations had significant increases in biomass yield over Kanlow while four populations had significant increases in ground cover over Kanlow (Table 3 ). Averaged across the five selected lowland populations evaluated at DeKalb, biomass yield increased from 9.20 to $11.38 \mathrm{Mg} \mathrm{ha}^{-1}$ (14\% increase; $\left.P=0.0034\right)$. Lowland populations selected for high biomass yield did not differ from populations selected for a combination of high biomass yield and high quality (HYLD vs. NETO in Table 3).

As with the upland selections, there were no effects of selection on quality traits expressed on a unit dry matter basis. Both ethanol production and heating value production showed evidence of an increase associated with the realized gains in biomass yield (Table 4). Three of the five individual populations were significantly improved with respect to ethanol production and heating value production, 
Table 4. Mean ethanol production and high heating value production of Kanlow lowland switchgrass and five populations derived by selection from within Kanlow. Means were computed over four replicates, four locations, and $3 \mathrm{yr}$.

\begin{tabular}{lcc}
\hline \multicolumn{1}{c}{ Population } & $\begin{array}{c}\text { Ethanol } \\
\text { production }\end{array}$ & $\begin{array}{c}\text { High heating } \\
\text { value production }\end{array}$ \\
\hline Kanlow & L ha $^{-1}$ & GJ ha \\
K & 1687 & 155.1 \\
K N1 Syn 2 & 1977 & 176.7 \\
K N1 E HYLD & 1863 & 178.9 \\
K N1 L HYLD & 2345 & 212.9 \\
K N1 NETO2 & 2299 & 218.1 \\
K N1 NETO3 & 2142 & 210.0 \\
LSD(0.01) & 410 & 39.6 \\
\hline
\end{tabular}

${ }^{\dagger} \mathrm{E}$, early maturity; HYLD, high biomass yield; K, Kanlow; L, late maturity; NETO, Nebraska Ethanol Index; Syn, synthetic.

ranging from 27 to $39 \%$ higher in these traits compared to Kanlow $(P<0.01)$. Across all five selected lowland populations, the average increase was $26 \%$ in ethanol production $(P=0.0004)$ and $24 \%$ in heating value production $(P=$ 0.0005). As observed for biomass yield, lowland populations selected for high biomass yield did not differ from populations selected for a combination of high biomass yield and high quality (HYLD vs. NETO in Table 4).

\section{Upland vs. Lowland and Upland $x$ Lowland Hybrids}

There were no significant relationships of biomass yield or ground cover to latitude of the evaluation sites for upland and hybrid switchgrasses (Fig. 3). These groups all had extremely high ground cover $(>90 \%)$ and relatively high biomass yield at all locations. Conversely, lowland populations declined linearly in both biomass yield and ground cover with latitude of the evaluation site. The average losses for lowland switchgrasses were $1.34 \mathrm{Mg} \mathrm{ha}^{-1}$ and $14 \%$ units for each additional degree of northern latitude.

Both midparent and high-parent advanced-generation heterosis effects were significant for biomass yield at all locations (Table 5). Midparent heterosis effects for ground cover were significant at all locations, but highparent heterosis effects for ground cover were not significant due to the high survivorship of the upland parent, Summer. Average midparent heterosis was $80 \%$ for biomass yield and 39\% for ground cover. Average high-parent heterosis was $43 \%$ for biomass yield and $4 \%$ for ground cover. Heterosis effects varied somewhat across evaluation sites, ranging from 28 to $70 \%$ for high-parent heterosis of biomass yield, with the largest effect observed at DeKalb. Reciprocal effects were significant for biomass yield only at Arlington and Marshfield, for which hybrids with the lowland female $(\mathrm{S} \times \mathrm{K})$ had 15 to $17 \%$ higher biomass yield than hybrids with the upland female $(\mathrm{K} \times \mathrm{S})$.

There were no significant heterosis effects for ethanol or high heating value expressed as concentration on a unit dry matter basis (data not shown). Among the K N1
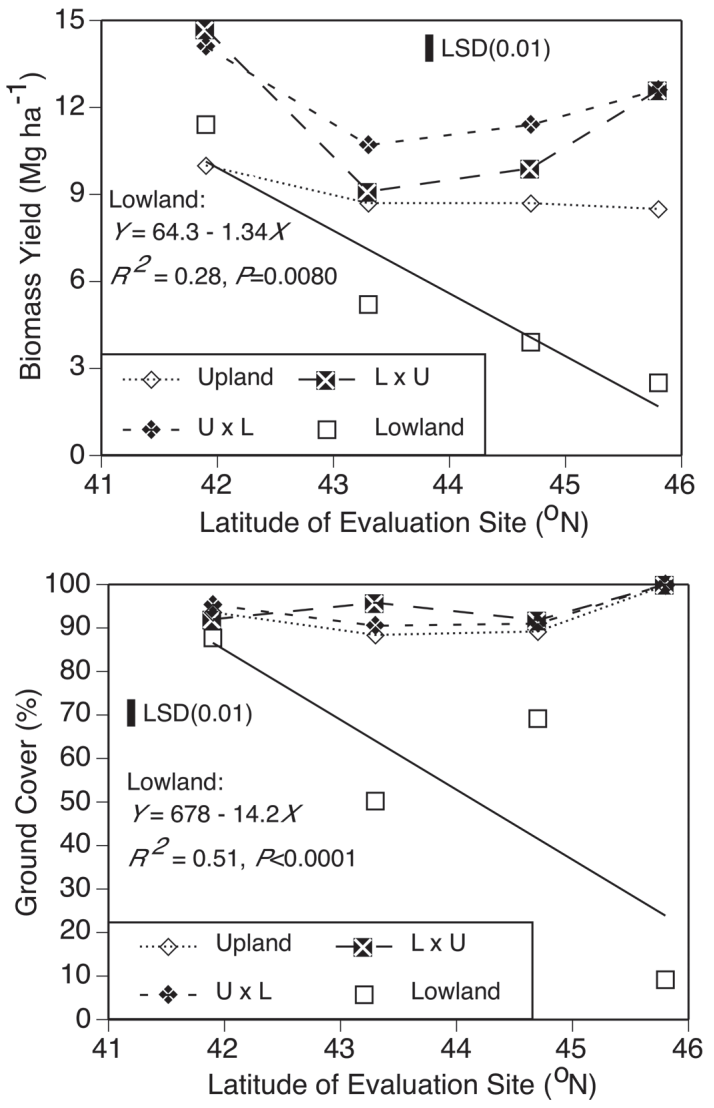

Figure 3. Relationship between biomass yield or ground cover and latitude of the four evaluation sites, presented separately for four groups of populations: mean of upland ecotypes $(U ; n=25)$, mean of lowland ecotypes ( $L ; n=6)$, mean of $U \times L$ hybrids $(n=2)$, and mean of $L \times U$ hybrids $(n=2)$.

populations, selection for biomass yield and maturity had a greater effect than the single cycle of index selection for either low lignin or high cellulose (Table 4). Both midparent and high-parent heterosis effects were significant for both ethanol production and high heating value production at all four evaluation locations (Table 6). The mean heterosis for ethanol production was $84 \%$ compared to the midparent and 44\% compared to the high parent (Summer at all locations, except DeKalb). The mean heterosis for high heating value production was $81 \%$ compared to the midparent and $46 \%$ compared to the high parent.

\section{DISCUSSION}

\section{Breeding for Biomass Yield}

While the first round of new biomass-type cultivars is expected to provide a significant increase in biomass yield, sustained long-term genetic gains will be required to develop biomass cultivars of switchgrass that significantly reduce the production risks associated with climate change, variable weather, and potential pest problems. Our results provide the first estimates of medium- to long-term gains that can be achieved by selection for biomass yield in switchgrass. Current production of switchgrass biomass in 
Table 5. Mean biomass yield and ground cover of Summer (S) upland switchgrass, Kanlow (K) lowland switchgrass, and two groups of third-generation hybrids between Summer and Kanlow (first listed parent is the male), including $P$-values for comparisons of reciprocals and advanced-generation heterosis effects in parentheses. Means were computed over four replicates, $3 \mathrm{yr}$, and two hybrid populations each for $\mathrm{K} \times \mathrm{S}(\mathrm{f})$ and $\mathrm{S} \times \mathrm{K}(\mathrm{f})$.

\begin{tabular}{|c|c|c|c|c|c|}
\hline \multirow[b]{3}{*}{ Population } & \multicolumn{4}{|c|}{ Evaluation site } & \multirow[b]{3}{*}{ Mean } \\
\hline & \multicolumn{4}{|c|}{ DeKalb, Arlington, Marshfield, Spooner, } & \\
\hline & IL & WI & WI & WI & \\
\hline & \multicolumn{5}{|c|}{ Biomass yield $\left(\mathrm{Mg} \mathrm{ha}^{-1}\right)$} \\
\hline Summer & 8.48 & 7.24 & 8.31 & 9.20 & 8.31 \\
\hline Kanlow & 9.20 & 4.57 & 3.16 & 2.52 & 4.87 \\
\hline$K \times S(f)$ & 14.68 & 9.10 & 9.88 & 12.62 & 11.58 \\
\hline$S \times K(f)$ & 14.14 & 10.68 & 11.35 & 12.58 & 12.20 \\
\hline$K \times S(f)$ vs. $S \times K(f)$ & $(0.4986)$ & $(0.0337)$ & $(0.0529)$ & $(0.9454)$ & $(0.0898)$ \\
\hline $\begin{array}{l}\text { Midparent } \\
\text { heterosis }\end{array}$ & $(<0.0001)$ & $(<0.0001)$ & $(<0.0001)$ & $(<0.0001)$ & $(<0.0001)$ \\
\hline \multirow{2}{*}{$\begin{array}{l}\text { High-parent } \\
\text { heterosis }\end{array}$} & $(<0.0001)$ & $(0.0016)$ & $(0.0071)$ & $(<0.0001)$ & $(<0.0001)$ \\
\hline & \multicolumn{4}{|c|}{ Ground cover (\%) } & 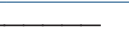 \\
\hline Summer & 92 & 82 & 92 & 100 & 91 \\
\hline Kanlow & 82 & 30 & 56 & 10 & 45 \\
\hline$K \times S(f)$ & 92 & 96 & 92 & 100 & 95 \\
\hline$S \times K(f)$ & 95 & 91 & 91 & 100 & 94 \\
\hline$K \times S(f)$ vs. $S \times K(f)$ & $(0.2146)$ & $(0.4551)$ & $(0.8890)$ & $(1.0000)$ & $(0.8006)$ \\
\hline $\begin{array}{l}\text { Midparent } \\
\text { heterosis }\end{array}$ & $(0.0029)$ & $(<0.0001)$ & (0.0002) & $(<0.0001)$ & $(<0.0001)$ \\
\hline $\begin{array}{l}\text { High-parent } \\
\text { heterosis }\end{array}$ & $(0.4669)$ & $(0.1405)$ & $(0.9834)$ & (0.9572) & (0.3201) \\
\hline
\end{tabular}

the northern United States is limited to upland ecotypes (Perrin et al., 2008; Shinners et al., 2010). Sustained rates of gain similar to that observed in WS4U upland switchgrass $\left(0.71 \mathrm{Mg} \mathrm{ha}^{-1}\right.$ per cycle; $4 \% \mathrm{yr}^{-1}$ ) would result in a $50 \%$ increase in biomass yield after an additional three to four selection cycles, achievable by 2020 at the current rate of progress. A high degree of outcrossing, high levels of heterogeneity, and high levels of heterozyosity in switchgrass have preserved large amounts of genetic variability within populations such as WS4U, Cave-inRock, and Kanlow (Casler et al., 2007b), which have been major targets for intrapopulation improvement (Vogel et al., 1996). Sustainable long-term gains for biomass yield in other perennial grasses suggest that similar expectations are reasonable for switchgrass (Burton and Mullinix, 1998; Wilkins and Humphreys, 2003). The mean rate of gain within Cave-in-Rock $\left(0.7 \% \mathrm{yr}^{-1}\right)$ was significantly lower than observed within WS4U, probably due to reduced genetic variation within this single source-identified population, compared to the broad-based WS4U. Simultaneous selection for increased biomass yield and biomass quality within Cave-in-Rock likely contributed to a reduced rate of gain for biomass yield in this population (Casler and Vogel, 1999).
Table 6. Mean ethanol production and high heating value for Summer (S) upland switchgrass, Kanlow (K) lowland switchgrass, and two groups of third-generation hybrids between Summer and Kanlow (first listed parent is the male), including $P$-values for comparisons of reciprocals and advanced-generation heterosis effects in parentheses. Means were computed over four replicates, $3 \mathrm{yr}$, and two hybrid populations each for $\mathrm{K} \times \mathrm{S}(\mathrm{f})$ and $\mathrm{S} \times \mathrm{K}(\mathrm{f})$.

\begin{tabular}{|c|c|c|c|c|c|}
\hline \multirow[b]{2}{*}{ Population } & \multicolumn{4}{|c|}{ Evaluation site } & \multirow[b]{2}{*}{ Mean } \\
\hline & $\begin{array}{l}\text { DeKalb, } \\
\text { IL }\end{array}$ & $\begin{array}{c}\text { Arlington, } \\
\text { WI }\end{array}$ & $\begin{array}{c}\text { Marshfield, } \\
\text { WI }\end{array}$ & $\begin{array}{c}\text { Spooner, } \\
\text { WI }\end{array}$ & \\
\hline & \multicolumn{5}{|c|}{ Ethanol production $\left(\mathrm{L} \mathrm{ha}^{-1}\right)$} \\
\hline Summer & 2994 & 2483 & 2919 & 3492 & 2972 \\
\hline Kanlow & 3087 & 1488 & 900 & 1272 & 1687 \\
\hline$K \times S(f)$ & 5231 & 3282 & 3337 & 4877 & 4182 \\
\hline$S \times K(f)$ & 4957 & 3910 & 3967 & 4769 & 4401 \\
\hline$K \times S(f)$ vs. $S \times K(f)$ & (0.3394) & $(0.0240)$ & $(0.0282)$ & $(0.7302)$ & $(0.1697)$ \\
\hline $\begin{array}{l}\text { Midparent } \\
\text { heterosis }\end{array}$ & $(<0.0001)$ & $(<0.0001)$ & $(<0.0001)$ & $(<0.0001)$ & $(<0.0001)$ \\
\hline \multirow{2}{*}{$\begin{array}{c}\text { High-parent } \\
\text { heterosis }\end{array}$} & $(<0.0001)$ & $(0.0004)$ & $(0.0215)$ & $(0.0008)$ & $(<0.0001)$ \\
\hline & \multicolumn{5}{|c|}{ _ High heating value production (GJ ha ${ }^{-1}$ ) } \\
\hline Summer & 142.1 & 121.4 & 139.9 & 156.2 & 139.9 \\
\hline Kanlow & 155.1 & 72.8 & 48.8 & 63.9 & 85.1 \\
\hline$K \times S(f)$ & 247.0 & 153.2 & 166.9 & 227.7 & 198.7 \\
\hline$S \times K(f)$ & 238.4 & 179.9 & 192.5 & 223.8 & 208.6 \\
\hline$K \times S(f)$ vs. $S \times K(f)$ & $(0.5252)$ & $(0.0349)$ & $(0.0563)$ & $(0.7855)$ & $(0.0861)$ \\
\hline $\begin{array}{l}\text { Midparent } \\
\text { heterosis }\end{array}$ & $(<0.0001)$ & $(<0.0001)$ & $(<0.0001)$ & $(<0.0001)$ & $(<0.0001)$ \\
\hline $\begin{array}{c}\text { High-parent } \\
\text { heterosis }\end{array}$ & $(<0.0001)$ & $(0.0017)$ & $(0.0081)$ & $(0.0002)$ & $(<0.0001)$ \\
\hline
\end{tabular}

Following these improvements in biomass yield of upland ecotypes, the next realizable gains in biomass yield will accrue from the development of northern-adapted lowland ecotypes. Lowland ecotypes occur naturally only in HZ6 and above (Casler et al., 2012). Recent reports have identified a relatively high frequency of lowland accessions in the Northeastern United States (Zhang et al., 2011a, 2011b) and as rare members of isolated prairie remnants of Illinois and Iowa (Lu et al., 2013). Lowland switchgrass has a distinct biomass-yield advantage over upland switchgrass, an effect that decreases linearly with increasing latitude or decreasing mean temperature (Casler, 2012). This effect has yet to be observed or quantified in HZ3 through HZ5 due to the lack of adaptation of current public and commercial lowland cultivars.

Selection within Kanlow switchgrass has focused largely on biomass yield and survivorship following harsh winter conditions in eastern Nebraska (HZ5), resulting in realized gains in another HZ5 location, DeKalb, IL. These results confirm predictions made by Casler et al. (2007a, 2007b) that genetic improvements made within a hardiness zone should largely be transferable across the majority of that zone, in this case two locations separated by $700 \mathrm{~km}$. However, the lack of progress in lowland switchgrass improvement at the three Wisconsin locations drives 
home the converse point: breeding progress made within a particular hardiness zone is not necessarily realized when moving germplasm out of that hardiness zone (Casler et al., 2007a, 2007b; Vogel et al., 2005). Despite the conclusion, significant gains were observed for ground cover within lowland switchgrass populations at Arlington and Marshfield, WI, two HZ4 locations (Table 3). Furthermore, biomass yield of these populations averaged 19\% higher than for Kanlow at these two locations, so the lack of statistical significance was due to insufficient replication and low power for each individual location, not due to lack of true differences. Therefore, as additional gains occur, the genetic improvements made in these lowland populations should be realized in HZ4 through HZ6 (Casler et al., 2007a, 2007b; Vogel et al., 2005). Lowland switchgrass was $14 \%$ higher in biomass yield and similar in ground cover compared to upland switchgrass at DeKalb, IL, so it is reasonable to expect that selection for increased survivorship and biomass yield within harsh HZ4 and HZ5 environments could create adapted lowland germplasm that has higher yield potential than locally adapted upland germplasm. Upland cultivars complete anthesis in early to mid August while lowland cultivars do not begin anthesis until early September at Arlington and Marshfield, WI (data not shown), providing lowland cultivars with an additional 4 to $5 \mathrm{wk}$ of potential biomass accumulation time.

Finally, upland $\times$ lowland hybrids represent a third mechanism for improving biomass yield of switchgrass (Martinez-Reyna and Vogel, 2008; Vogel and Mitchell, 2008). Of the three strategies for improving biomass yield of switchgrass addressed in this paper, the hybrids had the broadest success and applicability. Both midparent and high-parent heterosis effects were similar to those observed in eastern Nebraska (Martinez-Reyna and Vogel, 2008; Vogel and Mitchell, 2008) and were similar across four locations that spanned HZ3 to HZ5 in this study. Despite the fact that Kanlow was the high parent at DeKalb and Summer was the high parent at the three Wisconsin locations, hybrids were always significantly higher in biomass yield compared to the high parent, with average heterosis (43\%) exceeding that observed in Nebraska (MartinezReyna and Vogel, 2008; Vogel and Mitchell, 2008). These hybrids clearly combined the high biomass-yield potential of Kanlow with the high survivorship and cold tolerance of Summer, resulting in adaptation in HZ3 to HZ5.

To date, these four hybrid populations represent the only upland $\times$ lowland switchgrass hybrids to be evaluated in field experiments. These hybrid populations trace back to a small group of unselected plants from the cultivars Summer and Kanlow (Vogel and Mitchell, 2008). Both parents were selected based on phenotypic performance in breeding nurseries and on their ability to produce flowering panicles for crossing in the glasshouse. While Summer is clearly well adapted to these four locations, Kanlow is not adapted to the three Wisconsin locations, suggesting that there is significant room for improvement of the hybrid populations by intrapopulation improvement within both upland and lowland ecotypes, as described earlier (Fig. 1; Tables 2 and 3). Because of the limited germplasm base, the lack of selection for combining ability, and the categorical exclusion of any octoploid germplasm to date (Vogel and Mitchell, 2008), these hybrids likely represent only a fraction of the potential gains to be made using upland $\times$ lowland switchgrass hybrids in an improvement program. For example, in maize (Zea mays L.), selection of superior hybrids has included long-term development of consistent heterotic groups, modification of breeding methods to include routine testing of reciprocal combining ability, and an efficient mechanism to produce and market $F_{1}$ hybrid seed (Troyer, 2006). Two proposals have been put forth for hybrid seed production: (i) vegetative propagation of superior genotypes (Casler, 2012) and development of inbred lines (Liu et al., 2013). As these challenges are solved in switchgrass and as biomass yield and adaptation of both upland and lowland ecotypes are improved, it is likely that higher gains will be realized by the use of upland $\times$ lowland switchgrass hybrids.

\section{Biomass Quality}

Measured amounts of ethanol yield and heating value per unit of dry matter did not respond to any of the biomass improvement strategies. This result suggested a nearzero genetic correlation between biomass yield and both of these measures of biomass quality. However, only a single cycle of selection and breeding for biomass quality traits was conducted in the lowland and hybrid lineages and major improvements were not expected. Correlated responses were observed for both quality components expressed on a unit-land-area basis, in direct proportion to the observed gains in biomass yield. Increases in ethanol production and heating value yield can be directly translated to increases in net energy conversion per unit of land area for all three biomass yield improvement strategies. Furthermore, any successful strategy to improve biomass yield of switchgrass is platform neutral, as it clearly results in increases in net energy yield per hectare for both fermentation and combustion platforms. We do not yet have NIRS calibrations to predict pyrolysis products and yields, but it is likely that increases in biomass yield of switchgrass would also result in net increases in energy production from pyrolysis.

Perrin et al. (2008) illustrated the economic impact of environmental variation for biomass production of switchgrass on 10 farms in the northern plains region of the United States. Mean farm-gate production costs decreased by US $\$ 9 \mathrm{Mg}^{-1}$ for each $1 \mathrm{Mg} \mathrm{ha}^{-1}$ increase in 5-yr mean biomass yield (Perrin et al., 2008; our computations). The three biomass-yield improvement strategies used in this 
study resulted in a range of 30 to $45 \%$ increases in biomass yield, decreasing expected farm-gate production costs by approximately $\$ 20$ to $30 \mathrm{Mg}^{-1}$. Because these yield gains were achieved without an increase in $\mathrm{N}$ fertilizer, there was no added cost associated with agronomic inputs. Based on the two biomass-quality traits, these biomassyield improvements would translate to an increase of 700 to $1500 \mathrm{~L} \mathrm{ha}^{-1}$ in ethanol production or an increase of 40 to $70 \mathrm{GJ} \mathrm{ha}^{-1}$ in high heating value production.

\section{CONCLUSIONS}

Biomass yield improvements can be made in switchgrass, by application of sustained long-term selection and breeding methods. The long-term nature of both breeding programs described in this paper, involving 12 to $16 \mathrm{yr}$ of uninterrupted effort, was a critical component of our ability to achieve gains of 30 to $45 \%$ in biomass yield. Both intra- and interpopulation improvement methods were highly successful due to moderately high heritability of biomass yield. Genotypes with superior breeding value can be identified within spaced-planted nurseries of unreplicated genotypes, as long as selection intensities are maintained at a high level and some effort is made to control spatial or environmental variability. Selection experiments have confirmed predictions made from regional cultivar evaluations, that selected populations are broadly adapted within a hardiness zone and that some improved populations are sufficiently adapted one hardiness zone above and below their zone of origin to be of utility in a biomass production system.

The future of biomass-yield improvement for switchgrass in the northern United States will necessarily involve the adaptation of southern germplasm to northern environments. Specifically, this will involve collection, selection, breeding, and extensive evaluation of lowland germplasm collected from throughout the southern United States. Because lowland populations are generally unadapted to the northern United States but contain an extremely low frequency of plants capable of surviving in HZ4 and HZ5 (Zhang et al., 2011a, 2011b), this will be necessarily a long-term effort to screen hundreds of thousand of genotypes. The late-flowering trait of lowland ecotypes must be retained during selection and breeding, to ensure that these populations will be capable of using the entire growing season. Because lowland genotypes are incapable of setting seed north of $41^{\circ} \mathrm{N}$ latitude, seed production of selected genotypes is a massive complication for some breeding programs, requiring partnership with breeding or agronomic programs at more southern latitudes. Because both intra- and interpopulation improvements are capable of significant long-term biomass-yield gains, stacking these yield gains represents a realistic goal for potentially doubling biomass yield in northern environments by 2020 .
Finally, realized gains in biomass yield were platform neutral with respect to fermentation and combustion platforms for conversion of biomass to energy. Increases in biomass yield of switchgrass were translated directly and linearly to realized gains in net energy per hectare, at the same time significantly decreasing the expected cost and increasing the profitability of biomass at the farm gate. Based on any of the three improvement strategies used in this study, there was zero genetic correlation between biomass yield and biomass quality, suggesting that future improvements in switchgrass could be achieved simultaneously for both biomass quantity and quality.

\section{Acknowledgments}

This research was funded in part by congressionally allocated funds through USDA-ARS and by the Agriculture and Food Research Initiative Competitive Grant No. 2011-68005-30411 from the USDA National Institute of Food and Agriculture. We thank Nick Baker and Jacob Karlen, USDA-ARS, Madison, WI, and Steve Masterson, USDA-ARS, Lincoln, NE, for technical assistance and support with field, greenhouse, and laboratory activities.

\section{References}

Alderson, J., and W.C. Sharp. 1994. Grass varieties in the United States. Agric. Handb. 170. Soil Conserv. Serv., USDA, Washington, DC.

Burton, G.W., and B.G. Mullinix. 1998. Yield distributions of spaced plants with Pensacola bahiagrass populations developed by recurrent restricted phenotypic selection. Crop Sci. 38:333336. doi:10.2135/cropsci1998.0011183X003800020008x

Casler, M.D. 2010. Changes in mean and genetic variance during two cycles of within-family selection in switchgrass. BioEnergy Res. 3:47-54. doi:10.1007/s12155-009-9071-9

Casler, M.D. 2012. Switchgrass breeding, genetics, and genomics. In: A. Monti, editor, Switchgrass. Springer, New York, NY. p. 29-54.

Casler, M.D., R.B. Mitchell, and K.P. Vogel. 2012. Switchgrass. In: C. Kole, et al., editors, Handbook of bioenergy crop plants. Vol. 2. Taylor and Francis, New York, NY. p. 563-590.

Casler, M.D., C.A. Stendal, L. Kapich, and K.P. Vogel. 2007 b. Genetic diversity, plant adaptation regions, and gene pools for switchgrass. Crop Sci. 47:2261-2273. doi:10.2135/cropsci2006.12.0797

Casler, M.D., and K.P. Vogel. 1999. Accomplishments and impact from breeding for increased forage nutritional value. Crop Sci. 39:12-20. doi:10.2135/cropsci1999.0011183X003900010003x

Casler, M.D., K.P. Vogel, and A.C. Beal. 2006. Registration of WS4U and WS8U switchgrass germplasms. Crop Sci. 46:998-999. doi:10.2135/cropsci2005.04-0020

Casler, M.D., K.P. Vogel, C.M. Taliaferro, N.J. Ehlke, J.D. Berdahl, E.C. Brummer, R.L. Kallenbach, C.P. West, and R.B. Mitchell. 2007a. Latitudinal and longitudinal adaptation of switchgrass populations. Crop Sci. 47:2249-2260. doi:10.2135/cropsci2006.12.0780

Casler, M.D., K.P. Vogel, C.M. Taliferro, and R.L. Wynia. 2004. Latitudinal adaptation of switchgrass populations. Crop Sci. 44:293-303. 
Cathey, H.M. 1990. USDA plant hardiness zone map. USDA Misc. Publ. No. 1475. U.S. Natl. Arboretum. USDA-ARS, Washington, DC.

Fike, J.H., D.J. Parrish, D.D. Wolf, J.A. Balasko, J.T. Green Jr., M. Rasnake, and J.H. Reynolds. 2006. Switchgrass production for the upper southeastern USA: Influence of cultivar and cutting frequency on biomass yields. Biomass Bioenergy 30:207-213. doi:10.1016/j.biombioe.2005.10.008

Hopkins, A.A., K.P. Vogel, and K.J. Moore. 1993. Predicted and realized gains from selection for in vitro dry matter digestibility and forage yield in switchgrass. Crop Sci. 33:253-258. doi:10.2135/cropsci1993.0011183X003300020007x

Hopkins, A.A., K.P. Vogel, K.J. Moore, K.D. Johnson, and I.T. Carlson. 1995. Genetic variability and genotype $\times$ environment interactions among switchgrass accessions from the Midwestern USA. Crop Sci. 35:565-571. doi:10.2135/cropsci 1995.0011183X003500020047x

Littell, R.C., G.A. Milliken, W.W. Stroup, and R.D. Wolfinger. 1996. SAS system for mixed models. SAS Institute, Inc., Cary, NC.

Liu, L., S.L. Thames, and Y. Wu. 2013. Lowland switchgrass plants in populations set completely outcrossed seeds under field conditions as assessed with SSR markers. BioEnergy Res. 6:1-7. doi:10.1007/s12155-012-9236-9

Lu, F., A.E. Lipka, J. Glaubitz, R. Elshire, J.H. Cherney, M.D. Casler, E.S. Buckler, and D.E. Costich. 2013. Switchgrass genomic diversity, ploidy, and evolution: Novel insights from a network-based SNP discovery protocol. PLoS Genet. 9(1):e1003215. doi:10.1371/journal.pgen.1003215

Martinez-Reyna, J.M., and K.P. Vogel. 2008. Heterosis in switchgrass: Spaced plants. Crop Sci. 48:1312-1320. doi:10.2135/ cropsci2007.12.0695

McLaughlin, S.B., and L.A. Kszos. 2005. Development of switchgrass (Panicum virgatum) as a bioenergy feedstock in the United States. Biomass Bioenergy 28:515-535. doi:10.1016/j.biombioe.2004.05.006

Missaoui, A.M., V.A. Fasoula, and J.H. Bouton. 2005. The effect of low plant density on response to selection for biomass production in switchgrass. Euphytica 142:1-12. doi:10.1007/ s10681-005-0149-y

Moore, K.J., L.E. Moser, K.P. Vogel, S.S. Waller, B.E. Johnson, and J.F. Pedersen. 1991. Describing and quantifying growth stages of perennial forage grasses. Agron. J. 83:1073-1077. doi:10.2134/agronj1991.00021962008300060027x

Núñez-Regueira, L., J. Rodríguez-Añón, J. Proupín-Castiñeiras, and A. Romero-García. 2001. Energetic evaluation of biomass originating from forest waste by bomb calorimetry. J. Therm. Anal. Calorim. 66:281-292. doi:10.1023/A:1012416521652

Perrin, R., K. Vogel, M. Schmer, and R. Mitchell. 2008. Farmscale production cost of switchgrass for biomass. BioEnergy Res. 1:91-97. doi:10.1007/s12155-008-9005-y

Rose, L.W., IV, M.K. Das, R.G. Fuentes, and C.M. Taliaferro. 2007. Effects of high- vs low-yield environments on selection for increased biomass yield of switchgrass. Euphytica 156:407-415. doi:10.1007/s10681-007-9390-x

Sanderson, M.A., P.R. Adler, A.A. Boateng, M.D. Casler, and G. Sarath. 2007. Switchgrass as a biofuels feedstock in the USA. Can. J. Plant Sci. 86:1315-1325. doi:10.4141/P06-136
Sanderson, M.A., R.L. Reed, W.L. Ocumpaugh, M.A. Hussey, G. Van Esbroeck, J.C. Read, C.R. Tischler, and F.M. Hons. 1999. Switchgrass cultivars and germplasm for biomass feedstock production in Texas. Bioresour. Technol. 67:209-219. doi:10.1016/S0960-8524(98)00132-1

Shenk, J.S., and M.O. Westerhaus. 1991. Population definition, sample selection, and calibration procedures for near infrared reflectance spectroscopy. Crop Sci. 31:469-474. doi:10.2135/ cropsci1991.0011183X003100020049x

Shinners, K.J., G.C. Boettcher, R.E. Muck, P.J. Weimer, and M.D. Casler. 2010. Harvest and storage of two perennial grasses as biomass feedstocks. Trans. Amer. Soc. Agric. Biol. Eng. 53:359-370.

Troyer, A.F. 2006. Adaptedness and heterosis in corn and mule hybrids. Crop Sci. 46:528-543. doi:10.2135/cropsci2005.0065

USDA-ARS. 2012. USDA plant hardiness zone map. USDAARS, Washington, DC. http://planthardiness.ars.usda.gov/ PHZMWEB/ (accessed 1 Jan. 2013).

Vogel, K.P. 2004. Switchgrass. In: L.E. Moser, L. Sollenberger, and B. Burson, editors, Warm-season $\left(\mathrm{C}_{4}\right)$ grasses. ASA-CSSA-SSSA Monograph. ASA-CSSA-SSSA, Madison, WI. p. 561-588.

Vogel, K.P. 2013. Comparison of two perennial grass breeding methods with switchgrass. Crop Sci. (in press) doi:10.2135/ cropsci2012.09.0559

Vogel, K.P., B.S. Dien, H.G. Jung, M.D. Casler, S.D. Masterson, and R.B. Mitchell. 2011. Quantifying actual and theoretical ethanol yields for switchgrass strains using NIRS analysis. BioEnergy Res. 4:96-110. doi:10.1007/s12155-010-9104-4

Vogel, K.P., A.A. Hopkins, K.J. Moore, K.D. Johnson, and I.T. Carlson. 1996. Registration of 'Shawnee' switchgrass. Crop Sci. 36:1713. doi:10.2135/cropsci1996.0011183X003600060051x

Vogel, K.P., and R.A. Masters. 2001. Frequency grid - A simple tool for measuring grassland establishment. J. Range Manage. 54:653-655. doi:10.2307/4003666

Vogel, K.P., and R.B. Mitchell. 2008. Heterosis in switchgrass: Biomass yield in swards. Crop Sci. 48:2159-2164. doi:10.2135/ cropsci2008.02.0117

Vogel, K.P., J.F. Pedersen, S.D. Masterson, and J.J. Toy. 1999. Evaluation of a filter bag system for NDF, ADF, and IVDMD forage analysis. Crop Sci. 39:276-279. doi:10.2135/cropsci199 9.0011183X003900010042x

Vogel, K.P., M.R. Schmer, and R.B. Mitchell. 2005. Plant adaptation regions: Ecological and climatic classification of plant materials. Rangeland Ecol. Manag. 58:315-319. doi:10.2111/1551-5028(2005)58[315:PAREAC]2.0.CO;2

Wilkins, P.W., and M.O. Humphreys. 2003. Progress in breeding perennial forage grasses for temperate agriculture. J. Agric. Sci. 140:129-150. doi:10.1017/S0021859603003058

Zhang, Y., J. Zalapa, A.R. Jakubowski, D.L. Price, A. Acharya, Y. Wei, E.C. Brummer, S.M. Kaeppler, and M.D. Casler. 2011a. Post-glacial evolution of Panicum virgatum: Centers of diversity and gene pools revealed by SSR markers and cpDNA sequences. Genetica (The Hague) 139:933-948.

Zhang, Y., J. Zalapa, A.R. Jakubowski, D.L. Price, A. Acharya, Y. Wei, E.C. Brummer, S.M. Kaeppler, and M.D. Casler. 2011b. Natural hybrids and gene flow between upland and lowland switchgrass. Crop Sci. 51:2626-2641. doi:10.2135/ cropsci2011.02.0104 